\title{
TINJAUAN SOSIOEKONOMI PEMANFAATAN FESES SAPI DENGAN TEKNOLOGI VERMICOMPOSTING
}

\section{Studi kasus di Kampung Papak Manggu Desa Cibodas Kecamatan Pasir Jambu Kabupaten Bandung}

\author{
Ratnaningsih Ruhiyat*, Dwi Indrawati, Etty Indrawati, Lailatus Siami \\ Fakultas Arsitektur Lanskap dan Teknologi Lingkungan, Universitas Trisakti \\ Jl. Kyai Tapa No.1, Grogol, Jakarta Barat, Indonesia \\ *ratnaningsih@trisakti.ac.id
}

\begin{abstract}
The Cibodas village is located in Pasir Jambu subdistrict at Bandung Regency, majority community livelihood edged is dairy cattle and agriculture. The problem of waste management in terms of cattle manure that could potentially produce methane (CH4) as one of the greenhouse gases $(G R K)$, and when the cattle manure dumped into the River then it can pollute the rivers directly. The purpose of this study is to see how big the benefits of social and economic aspects of the utilization of cattle manure at the farmer scale. A series of Research include : 1) collect opinions and responses to ranchers, livestock farmers and administrators, by filling the questionnaire against the management of the cattle manure, 2) Observations of operational at the process of vermicomposting in two locations, namely in kampong Papak Manggu and kampong Injeman Cibodas village, during the activities of Demontration plot. The observed data covering 1) production process of vermicomposting (worm production and the weight of the raw materials, daily activities, results of casting, mass balance and quality of organic fertilizer) 2) Required total working hour of process of vermicomposting 3) Space and facilities requirement 4) cost and price analysis. The research show that vermicompost is suitable to be implemented in processing cattle manure, base on the following reason : a) cleaning of the environment $b$ ) minimum labor requirement c) providing additional income d) availability of organic fertilizer.
\end{abstract}

Keywords: casting, cattle manure, socioeconomic, environtmental friendly, vermicompost

\begin{abstract}
Abstrak: Desa Cibodas terletak di kecamatan Pasir Jambu, Kabupaten Bandung, sebagian besar masyarakat bermata pencaharian bertenak sapi perah dan pertanian. Sehingga memiliki masalah dalam hal pengelolaan limbah feses sapi (kohe) yang berpotensi menghasilkan metana $(\mathrm{CH} 4)$ sebagai salah satu gas rumah kaca (GRK), dan apabila kohe dibuang langsung ke sungai maka dapat mencemari sungai secara langsung. Tujuan penelitian ini adalah melihat seberapa besar benefit dari aspek sosial dan ekonomi dari pemanfaatan kohe sapi perah skala rakyat dengan teknologi vermicompost. Rangkaian Penelitian meliputi 1) mengumpulkan pendapat dan tanggapan peternak, pengurus ternak dan petani, melalui pengisian kuesioner terhadap pengelolaan kohe, 2) Pengamatan kegiatanan operasional proses vermicompost di dua lokasi, yaitu di kampong Papak Manggu dan kampung Injeman Desa Cibodas, saat kegiatan Demplot. Data yang diamati meliputi 1) proses produksi vermicompost (berat cacing diawal dan diahir, berat bahan baku, kegiatan harian, hasil kascing, neraca massa dan kualitas casting) 2) Jumlah jam kerja dalam kegiatan prosesing composting, 3) kebutuhan ruang dan peralatan 4) analisa biaya dan harga. Penelitian ini menunjukan bahwa vermicompost sangat cocok diterapkan untuk mengolah kohe sapi, karena disamping menjadikan lingkungan kandang bersih, tenaga kerja yang dibutuhkan sedikit, juga dapat memberikan pengasilan tambahan bagi pengelola nya dengan menjual cacing dan pupuk kascing.
\end{abstract}

Kata Kunci: kascing, feses sapi, sosial-ekonomi, ramah lingkungan, vermicompost

\section{PENDAHULUAN}

Desa Cibodas adalah salah satu desa di kecamatan Pasir Jambu, Kabupaten Bandung, terletak pada ketinggian 10001200 meter diatas permukaan laut, dengan luas wilayah 1.926,3 Ha mencakup perkampungan, pesawahan, hutan lindung dan hutan produksi. Desa Cibodas merupakan desa penghasil susu sapi di kecamatan Pasirjambu, dengan jumlah peternak 130 orang, populasi ternak sapi perah produktif sekitar 542 ekor. Dampak dari peternakan sapi adalah adanya feses sapi (kohe) yang berpotensi menghasilkan metana (CH4) sebagai salah satu gas rumah kaca (GRK). Selain itu, apabila 
dalam penanganannya selama ini kohe dibuang langsung ke sungai maka dapat mencemari sungai secara langsung.

Dalam hal penangan feses sapi, beberapa peternak telah menggunakan teknologi biogas, namun dalam penerapannya belum dapat berjalan secara berkelanjutan. Hal ini dikarenakan peternak menjadikan biogas sebagai pekerjaan sampingan selain beternak. Sehingga, dalam operasionalnya tidak diutamakan dan akhirnya tidak bisa dimanfaatkan secara optimal. Selain itu lumpur effluent dari biogas pun masih belum memenuhi standar untuk dibuang langsung ke perairan. Pengolahan kohe menjadi pupuk meupakan alternatif lain yang lebih berkelanjutan, karena pupuk yang dihasilkan tersebut dapat digunakan sendiri atau dijual ke petani sekitar, karena sebagian penduduk sudah juga bertani. Secara statistik, jumlah penduduk Cibodas yang mempunyai pekerjaan tidak tetap terbilang cukup besar sebanyak 1078 orang.

Vermicomposting, adalah suatu tekonologi pengolahan limbah organik dengan memanfaatkan cacing sebagai decomposer, yang menghasilkan pupuk organik dan masa cacing ( Danilo R 2017); Sedangkan menurut Abdullah Hussaini (2013), Vermicompost adalah bioteknologi sederhana, yang melibatkan spesies tertentu dari cacing tanah, digunakan untuk memproses dan mengubah limbah dan memproduksi menjadi produk yang lebih baik dan berguna, selanjutnya Abdullah Hussaini (2013) menyampaikan bahwa memproduksi dan memanfaatkan Vermicompost merupakan kegiatan ramah lingkungan, melindungi dan memperbaiki kualitias lingkungan.

Kascing merupakan pupuk yang bersumber dari perombakan bahan-bahan organik dengan bantuan cacing (Sri Mursiani 2015), sedangkan berdasarkan hasil penelitian yang dilakukan Dedi (2013) yang disitasi oleh Sri Mursiani (2015) menyatakan, kombinasi pakan 50$65 \%$ bahan hijauan $+30 \%$ kotoran ditambah serbuk gergaji $10-15 \%$, dapat meningkatkan selera makan cacing dan menghasilkan kuantitas dan kualitas Kascing yang dihassilkan memiliki kualitas pupuk yang baik. Lebih jauh lagi P.K Sarma at al (2014) menyatakan bahwa kascing merupakan media yang sangat cocok bagi mikroba Azospirillum, Rhizobium dan pelarut phosphate, untuk hidup. Sejumlah penelitian telah menunjukkan, cacing tanah mempunyai kemampuan dalam mendekomposisi bermacam-macam limbah organik, seperti feses hewan, lumpur yang berasal dari saluran pembuangan air, sisa hasil panen dan limbah pertanian dan termasuk juga limbah yang berasal dari dapur. Penelitian ini bertujuan untuk melihat seberapa besar benefit dari aspek sosial dan ekonomi dari pemanfaatan kohe sapi perah skala rakyat di Desa Cibodas dengan menggunakan teknologi Vermicompost.

\section{METODOLOGI}

Tujuan penelitian ini adalah melihat seberapa besar benefit dari aspek sosial dan ekonomi, dalam upaya pemanfaatan feses sapi perah skala rakyat di Desa Cibodas dengan menggunakan teknologi vermicomposting. Penelitian berlangsung dari Bulan April 2018 - September 2018, dilakukan pada saat kegiatan Pengabdian Kepada Masyarakat kelompok Pemanfaat feses sapi di Desa Cibodas dan Kelompok Petani Organik di Desa Cisondari Kecamatan Pasir Jambu Kabupaten Bandung Provinsi Jawa Barat, Tahapan Kegiatan Penelitian meliputi: a) Penyebaran kuesioner kepada Peserta sebanyak 25 orang peserta pelatihan pemanfaatan kohe, yang terdiri dari 8 orang peternak, 7 orang calon pemanfaat kohe dan 10 orang petani organik, jajak pendapat melalui kuesioner dilaksanakan setelah selesai presentasi materi pelatihan b) Pengamatan kegiatanan operasional proses vermicompost di dua lokasi, yaitu di kampung Papak Manggu dan kampung Injeman Desa Cibodas, saat kegiatan 
Demplot. Data yang diamati meliputi : 1) proses produksi vermicompost (berat cacing diawal kegiatan dan saat panen, banyaknya feses sapi yang digunakan, kegiatan harian, hasil kascing, neraca massa dan kualitas kascing, 2) Jumlah jam kerja dalam kegiatan proses vermicompost, 3) kebutuhan ruang untuk proses dan peralatan 4) Analisis biaya dan pendapatan.

Dillon dan Hardaker (1993) yang disitasi Deepa at al (2014) menyatakan keuntungan kotor adalah perbedaan antara pengembalian kotor dan biaya variable. Keuntungan kotor dihitung dari Pengembalian kotor dikurang Total biaya variable. Waktu titik pulang pokok (Break even point) akan ditentukan secara grafik perpotongan kumulatif biaya dengan kumulatif pendapatan, sedang Return on Investment (ROI), bisa juga diartikan sebagai rasio laba bersih terhadap biaya, akan dihitung dengan rumus menghitung ROI adalah sebagai berikut:

$$
R O I=\frac{(\text { Total Penjualan }- \text { Total biaya })}{\text { Total biaya }}
$$

Penelitian kulaitatif dilakukan untuk melihat tanggapan masyarakat terhadap kegiatan pemanfaatan feses sapi dengan teknologi vermicompost selama demplot berlangsung ( 6 bulan) dengan cara observasi partisipatif dan wawancara yang mendalam kepada pengelola kohe, petani dan masyarakat di kampung Papak Manggu. Prof. Dr Sudarwan Danim (2013), menjelaskan bahwa penelitian kualittatif merupakan turunan dari filisofi fenomenologi, dengan prosedur kerja pengumpulan data yang paling umum dipakai adalah observasi partisipasi dan wawancara mendalam.

\section{HASIL DAN PEMBAHASAN \\ Hasil Jajak pendapat}

Untuk mendapatkan informasi seberapa jauh pengetahuan dan keinginan serta tanggapan anggota kelompok dalam hal mengelola feses sapi, telah dilakukan jajak pendapat melalui penyebaran kuesioner kepada tiga kelompok peserta pelatihan, yaitu peserta dari calon pengelola kohe anggota kelompok tani dan anggota peternak (pengisian kuesioner dilakukan setelah kegiatan pelatihan). Khusus dalam pembahasan ini disajikan hasil jajak pendapat dari 2 jenis pekerjaan, yaitu calon pengelola kohe dan peternak.

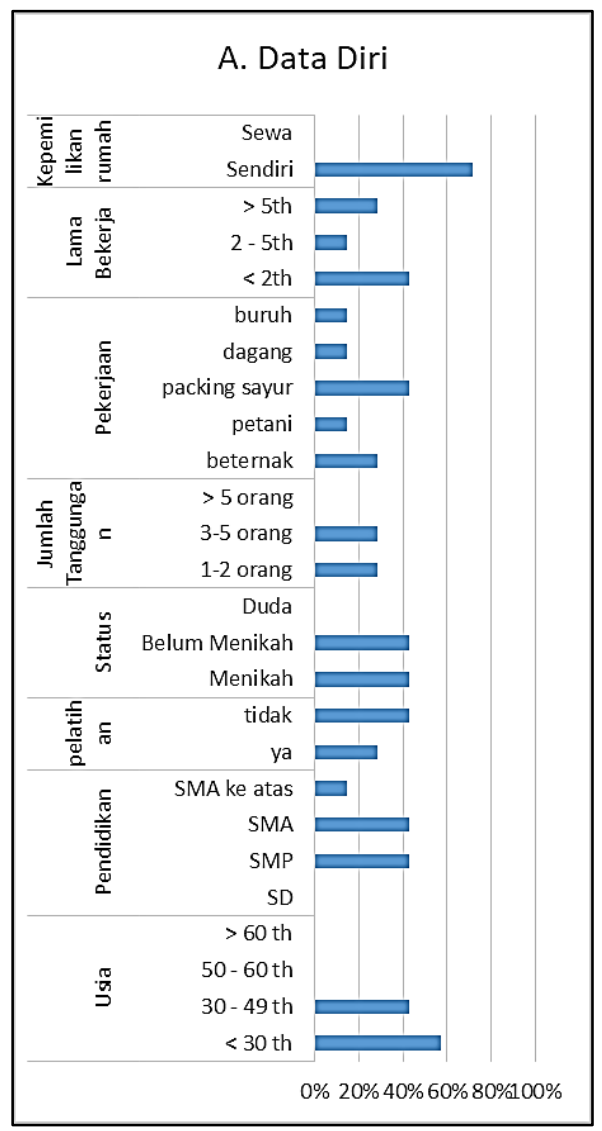

Gambar 1. (A) Grafik hasil Jajak Pendapat kepada Calon Pengelola Kohe

1. Tanggapan Calon Pengelola Kohe

Calon Pengelola kohe adalah anggota kelompok, yang bekerja serabutan, membantu peternak dalam mencari rumput, packing sayuram dan buruh tani, selain itu juga mereka melakukan pengolahan kohe menjadi pupuk organik dengan cara fermentasi, namun produksinya tidak kontinyu, berikut hasil jajak pendapat kepada mereka: Responden yang berminat untuk mengelola kohe mayoritas dalam usia muda dan produktif 
(<30th) dengan pendidikan maksimal SMA.

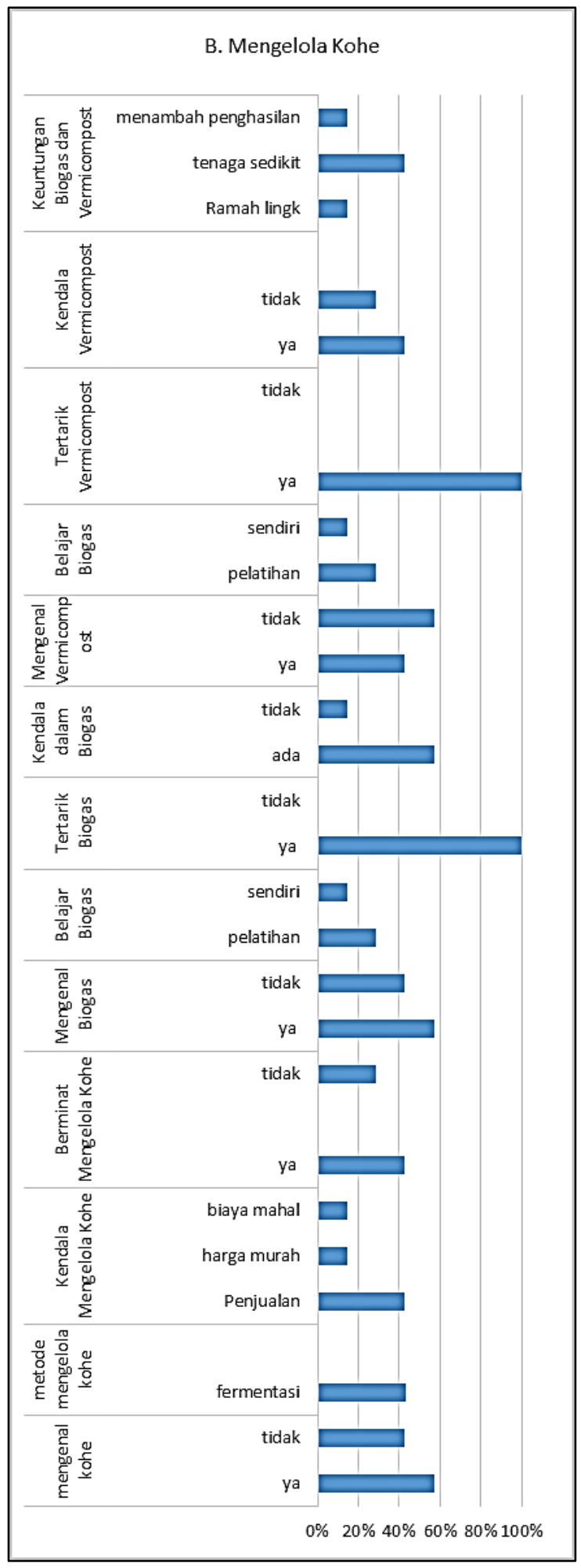

Gambar 1. (B) Grafik hasil Jajak Pendapat kepada Calon Pengelola Kohe

Responden mayoritas sudah berkeluarga dan memiliki tanggungan mulai dari satu hingga lima orang dan tinggal di rumah sendiri. Pekerjaan yang dilakukan selama ini adalah sebagai buruh packing sayur selama kurang dari dua tahun.

Mayoritas responden sudah mengetahui cara pengelolaan kohe dengan metode fermentasi. Anggapan kendala yang dihadapi adalah sulitnya pemasaran hasil olahan kohe, sedangkan biayanya mahal, tetapi responden masih berminat mengelola kohe, sepanjang ada pasarnya. Mayoritas responden sudah mengenal biogas dari pelatihan dan tertarik untuk menggunakan teknologi biogas. Mayoritas beranggapan ada kendala dalam penerapan biogas. Untuk teknologi vermicompost mayoritas responden belum mengenal, sedangkan responden yang sudah mengenal teknologi vermicompost dari pelatihan, mereka berpendapat, kendala yang terjadi sedikit dan manfaat yang didapat berupa minimalnya tenaga yang dibutuhkan, lebih ramah lingkungan serta dapat menambah penghasilan.

\section{Tanggapan Peternak}

Peternak di desa Cibodas mayoritas dalam usia produktif (30-49 th) dengan pendidikan SMA. Peternak mayoritas sudah berkeluarga dan memiliki tanggungan 3-5 orang dan tinggal di rumah sendiri. Lama kerja peternak mayoritas lebih dari 5 tahun. Selain itu, peternak juga memiliki lahan garapan milik sendiri dengan luas bervariasi antara $12-300 \mathrm{~m} 2$.

Sumber makanan ternak berasal dari hijauan dan jerami dari kebun, sawah maupun hutan. Jumlah ternak yang dipelihara bervariasi dari 2 hingga 5 ekor sapi ataupun kambing. Biaya pakan yang dikeluarkan perbulan juga bervariasi dari 100 ribu hingga 1,5 juta. Untuk sapi perah, susu yang dihasilkan sekitar 450 - 900 liter per bulan. Sehingga penghasilan yang didapatkan perbulan berkisar 300 ribu hingga 10 juta perbulan. Dalam memelihara ternak, mayoritas ada yang membantu dalam kesehariannya, peternak juga mencari rumput. Selama ini, penanganan feses sapi belum tertangani 
dan hanya ditumpuk saja. Peternak mayoritas tidak mengenal dan belum pernah melaksanakan peternakan probiotik. Hal ini dikarenakan ketidaktahuan akan peternakan probiotik dan anggapan bahwa teknologi tersebut mahal. Mayoritas peternak sapi perah menyalurkan hasil susu ke KUD.

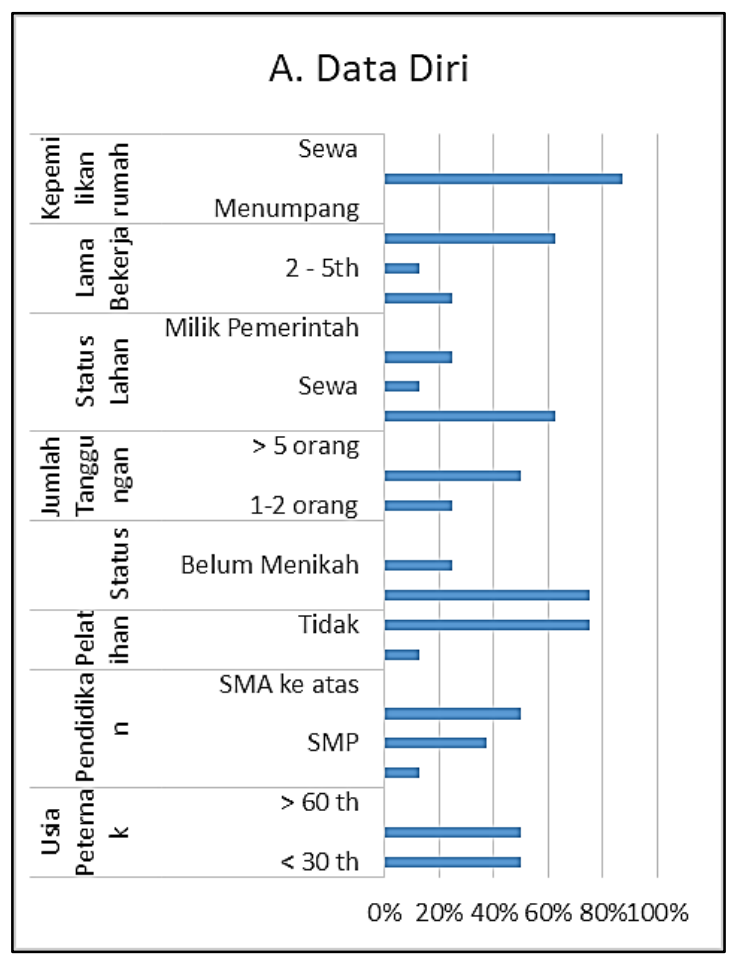

Gambar 2. (A) Grafik Hasil Jajak Pendapat Peternak

Peternak mayoritas tidak mengenal teknologi biogas dan berminat menggunakannya, sedangkan peternak yang tahu belajar dari pelatihan. Peternak beranggapan bahwa dalam menerapkan biogas tidak ada kendala. Untuk teknologi vermicompost mayoritas peternak juga tidak tahu, sedangkan sisanya belajar dari pelatihan yang pernah diikuti. Peternak beranggapan bahwa terdapat kendala dalam menerapkan vermicompost tetapi mengetahui manfaat yang dapat diperoleh darinya berupa ramah lingkungan (mayoritas), mengurangi limbah dan lebih hemat. Gambaran hasil jajak pendapat dari peternak dapat dilihat pada gambar 2 grafik hasil jajak pendapat dari peternak.

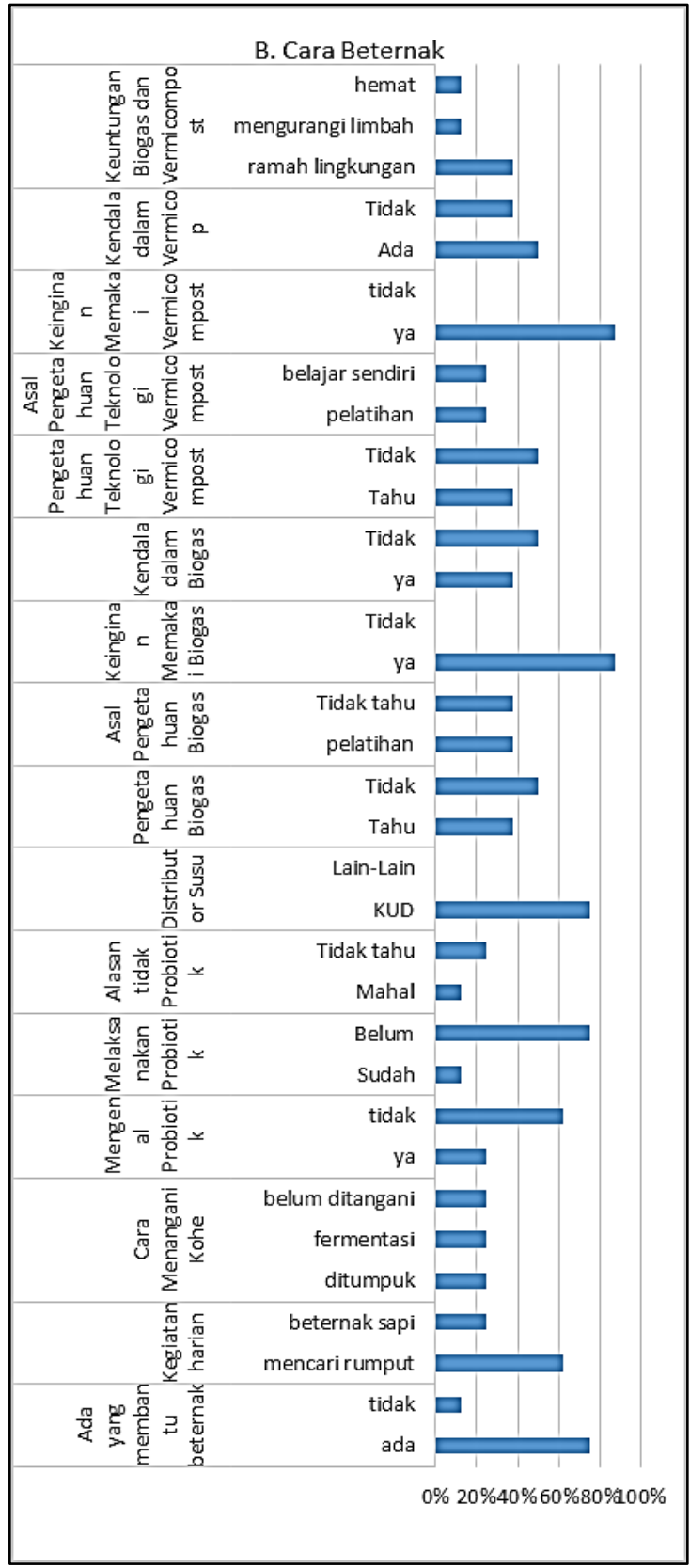

Gambar 2. (B) Grafik Hasil Jajak Pendapat Peternak

\section{Proses Vermikompos}

Dari pengamatan selama demplot/uji coba penggunaan reaktor biogas dan vermicompost, diperoleh data sebagai berikut : feses sapi yang dihasilkan sebanyak $20 \mathrm{~kg} / \mathrm{ekor} / \mathrm{hari}$, rata2 peternak memelihara 2 -3 ekor sapi, pada kegiatan demplot feses sapi dibersihkan dari lantai dengan disemprot air menggunakan selang, kemudian disapu dan didorong masuk ke reaktor biogas kapasitas $10 \mathrm{~m} 3$. Pembersihan kandang dilakukan 2 kali 
sehari. Tidak semua kohe sapi masuk ke dalam reaktor, karena kapasitas reaktor yang terbatas. Effluent biogas (lumpur) keluar dan ditampung dalam kolam penampungan.

Kohe sapi yang tidak masuk dalam reaktor biogas, ditumpuk pada kandang kosong ukuran $170 \mathrm{~cm}$ x $270 \mathrm{~cm}$ dengan tinggi bed $20 \mathrm{~cm}$. Ke dalam tumpukan kohe dimasukan cacing dewasa umur 2.5 bulan sebanyak $25 \mathrm{~kg}$. Pakan cacing diberikan dari lumpur biogas setiap 1 minggu sekali, sebanyak 6 x 10 liter lumpur (1 ember, kapasita 10 liter). Setiap bulan, vermicompost di bagi menjadi 3 bedeng dan masing masing bedeng ditambah kohe, untuk mencapai volume bedeng tersedia. Setelah 5 bulan kegiatan demplot, jumlah bedeng mencapai 8 bedeng ukuran $170 \mathrm{~cm}$ x $270 \mathrm{~cm}$ x $20 \mathrm{~cm}$ dan 8 bedeng ukuran $270 \mathrm{~cm}$ x $50 \mathrm{~cm}$ x 20 $\mathrm{cm}$ sehingga diperoleh biomasa sebanyak : kascing 6,666 kg dan $100 \mathrm{~kg}$ cacing. Selain itu masih terdapat 6 bed yang berisi telur dan $10 \quad \mathrm{~kg}$ cacing, untuk pengembangan berikutnya.

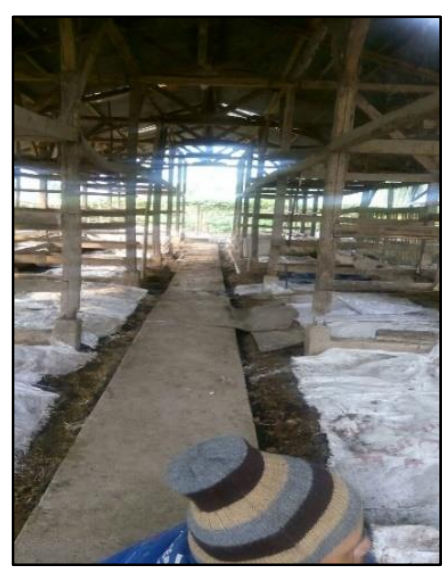

Gambar 3. Proses Vermicompost di Kampung Papak Manggu Desa Cibodas

Waktu yang digunakan oleh peternak dalam mengelola kohe untuk biogas dan kascing adalah 1) 60 menit untuk membersihkan kandang, mengisi reaktor biogas setiap harinya dan 2) 120 menit untuk panen cacing dewasa dan kascing termasuk memasukkan kascing ke dalam karung.
Pada Gambar 3. Menunjukan produksi vermicompost berjalan dengan baik dan berkembang, terlihat dari awalnya 2 bed telah berkembang menjadi 16 bed selama 6 bulan, kegiatan ini hanya merupakan kegiatan sambilan yang dikerjakan oleh peternak. Hasil analisis laboratorium terhadap kascing diperoleh dapat dilihat pada Tabel 1.

Tabel 1. Kualitas Pupuk Organik

\begin{tabular}{|l|c|c|}
\hline \multicolumn{1}{|c|}{ PARAMETER } & $\begin{array}{c}\text { Pupuk } \\
\text { organik } *\end{array}$ & $\begin{array}{c}\text { Pupuk } \\
\text { organik** }\end{array}$ \\
\hline pH 1:5 H2O & $4-9$ & 6.36 \\
\hline $\begin{array}{l}\text { C-Organik } \\
\text { (Gravimetri) (\%) }\end{array}$ & Min 15 & 25.06 \\
\hline Rasio C/N & $15-25$ & 16.89 \\
\hline $\begin{array}{l}\text { P2O5 + K2O + N } \\
\text { unsur hara) }\end{array}$ & Min 4 & 3.19 \\
\hline Kadar Air (\%) & $15-25$ & $22.9 \%$ \\
\hline
\end{tabular}

Hasil analisis laboratorium produksi kascing dengan bahan baku kohe murni $100 \%$, menunjukkan hampir semua parameter memenuhi standar kualitas pupuk organik berdasarkan Peraturan Menteri Pertanian no 70 /Permentan/ SR.140/10/2011 (Tabel 1), kecuali unsur hara makro masih dibawah minimal yaitu $3.19 \%$ (seharusnya diatas 4\%). Kualitas kascing bisa ditingkatkan dengan penambahan jerami padi misalnya, sebagaimana telah dilakukan oleh Badruzzaman dkk (2016), dalam penelitiannya menyimpulkan bahwa Campuran Feses Sapi perah dan jerami padi dalam vermicomposting telah meningkatkan unsur hara mlebehi $4 \%$, (dilihat dari hasil pejumlahan nilai $\mathrm{N}, \mathrm{P}_{2} \mathrm{O}_{5}$ dan $\mathrm{K}_{2} \mathrm{O}$ dalam prosentase).

\section{Biaya Investasi Vermicompost}

Demplot dilakukan di kandang sapi yang tidak digunakan, namun sesungguhnya untuk kegiatan vermicompost, tidak perlu bangunan yang mahal, cukup bangunan sederhana, terbuat dari tiang-tiang bambu, dengan atap dan dinding plastik, biaya 
penyiapan rumah vermicompost dengan tiang bambu, dan tutup/atap dari plastik dan para net adalah $\mathrm{Rp} 45.000 / \mathrm{m} 2$, jadi untuk 6 bed dengan ukuran $170 \mathrm{~cm}$ x 270 $\mathrm{cm}$ dibutuhkan investasi senilai $\mathrm{Rp}$ 1.239.300,- umur bangunan 5 tahun, jadi nilai penyusutan $\operatorname{Rp~20.655/bulan.~}$

Pembelian Cacing induk $25 \mathrm{~kg}$ x Rp $25.000=\mathrm{Rp} 650.000$,- Karena cacing ini terus berkembang biak tidak ada nilai penyusutan.

\section{Biaya Operasional}

1. Tenaga kerja yang dibutuhkan 60 menit x 30 hari/bulan +120 menit x 5 $\mathrm{kali} / \mathrm{bulan}=2.400$ menit $/$ bulan $=40$ jam/bulan

2. Biaya tenaga kerja $=40 \mathrm{jam} / \mathrm{bulan} \mathrm{x}$ Rp 60.000/6jam = Rp 400.000 /bulan. Dikerjakan oleh peternak, merupakan kerja sampingan

3. Biaya Tenaga kerja selama 5 bulan $\mathrm{Rp}$ 2.000.000

\section{Pendapatan dari Vermicompost}

1. Harga kascing Rp 250/kg dan cacing Rp 10.000/kg ditingkat petani

2. Pendapatan selama 5 bulan adalah sebagai berikut :
a) dari Kascing setiap bulan $=6.666$ $\mathrm{kg} / \mathrm{bulan} \mathrm{x} \mathrm{Rp} 250 / \mathrm{kg}=\mathrm{Rp}$ 1.666 .500
b) dari penjualan cacing dewasa $=$ $100 \mathrm{~kg} /$ bulan $\mathrm{x} \mathrm{Rp} 10.000=\mathrm{Rp}$ 1.000 .000
c) Total pendapatan selama 5 bulan $=\operatorname{Rp} 2.666 .500$

\section{Analisis Keuangan}

Dari hasil pengamatan lapangan pola pertumbuhan cacing sangat pesat, karena setiap cacing dewasa usia 3-12 bulan, bertelur setiap 2 minggu sebanyak 2-3 butir, maka dapat direncanakan panen Kascing dan Cacing selama 1 tahun dapat dilihat pada tabel 2 .

Tabel 2. Jumlah Cacing dan kascing yang dipanen setiap bulan selama 1 tahun

\begin{tabular}{|l|l|r|r|r|r|r|r|r|r|r|r|r|}
\hline Bulan & SAT & 1 & 2 & 3 & 4 & 5 & 6 & 7 & 8 & 10 & 11 & 12 \\
\hline Panen Cacing & $\mathrm{kg}$ & & & 0 & 25 & 100 & 100 & 150 & 200 & 200 & 200 & 200 \\
\hline Panen Kascing & $\mathrm{kg}$ & 300 & 300 & 600 & 900 & 900 & 900 & 900 & 900 & 900 & 900 & 900 \\
\hline
\end{tabular}

Biaya investasi sebesar Rp 1.889.300 dan biaya tenaga kerja $\mathrm{Rp} 400.000 /$ bulan, dan dengan harga kascing $\mathrm{Rp} 250 / \mathrm{kg}$ dan
Cacing $\mathrm{Rp} 10.000 / \mathrm{kg}$ maka dapat diperoleh gambaran Break Even Point (BEP) pada bulan 6 (gambar 4).

Tabel 3. Tabel Biaya dan Pendapatan Kumuliatif Usaha Vermicompost

\begin{tabular}{|l|c|c|c|c|c|c|c|c|c|c|c|c|}
\hline BULAN & \multicolumn{1}{|c|}{1} & \multicolumn{1}{c|}{3} & \multicolumn{1}{c}{3} & 4 & 5 & 6 & 7 & 8 & 9 & 10 & 11 & 12 \\
\hline BIAYA & $1,889,300$ & $2,289,300$ & $2,689,300$ & $3,089,300$ & $3,889,300$ & $4,289,300$ & $4,689,300$ & $5,089,300$ & $5,489,300$ & $5,889,300$ & $6,289,300$ & $6,689,300$ \\
\hline PENDAPATAN & - & 75,000 & 150,000 & $1,775,000$ & $3,000,000$ & $4,725,000$ & $6,950,000$ & $9,175,000$ & $11,400,000$ & $13,625,000$ & $15,850,000$ & $18,075,000$ \\
\hline
\end{tabular}

Kondisi tersebut telah memperhitungkan penghasilan tambahan bagi pengelola senilai Rp 400.000 setiap bulan dengan waktu kerja yang digunakan 40 jam/bulan. Waktu pengembalian modal, atau Break Even Point (titik impas) usaha vermicompost sangat pendek, karena biaya investasi yang dibutuhkan cukup rendah, dan biaya operasional vermicompost juga rendah, hal ini sesuai dengan hasil penelitian Bajracharya and Lakhe, 2013 yang disitasi oleh Devota at al (2014) menyatakan bahwa waktu tunggu untuk produksi pupuk siap berproduksi yang pendek yaitu 40 - 45 hari, dan modal investasi yang rendah maka waktu titik impas dicapai pada 1,72 tahun. 


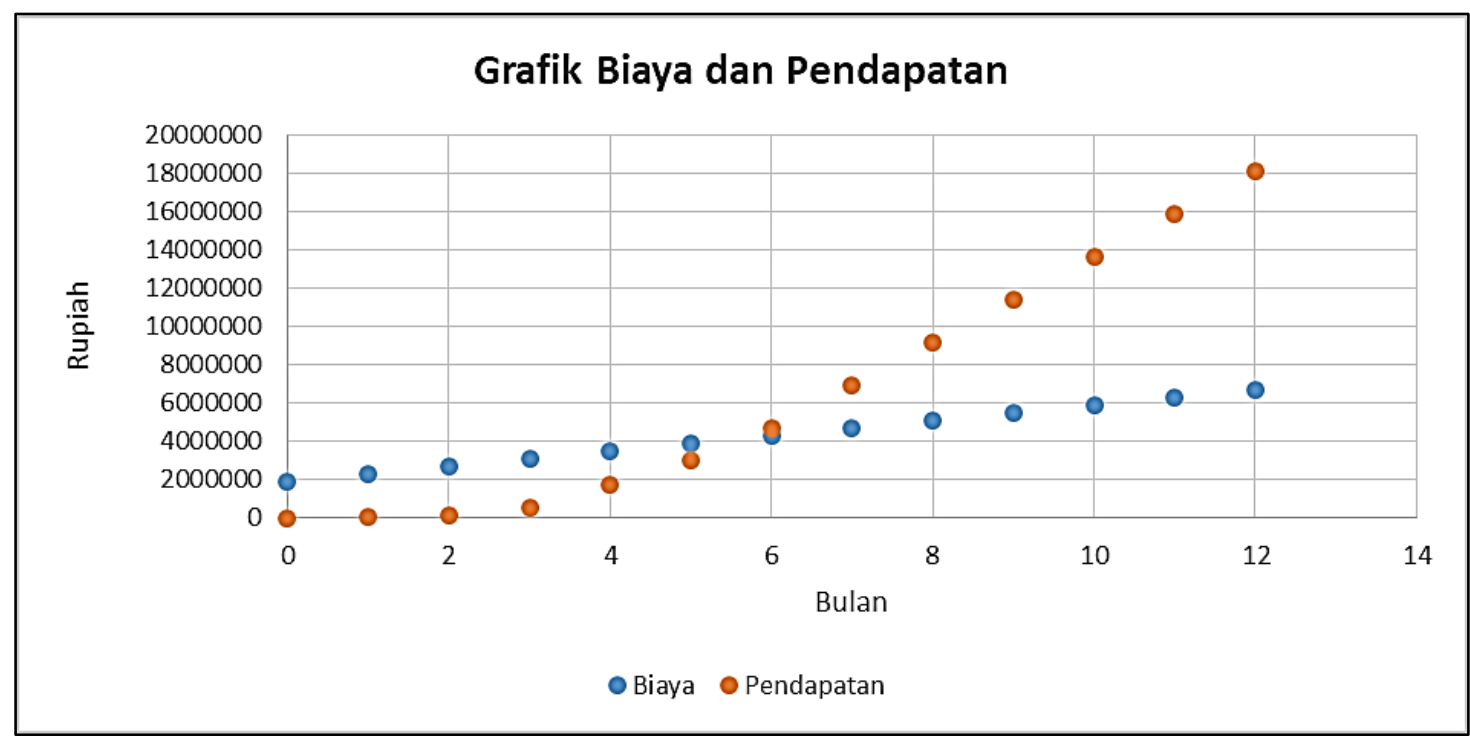

Gambar 4. Grafik Break Even Point Vermicompost

Kegiatan vermicompost dengan menggunakan feses sapi perah dicampur lumpur biogas memberikan nilai ROI dalam tahun pertama adalah $=$ $(18.075 .000-6.689 .300) / 6.689 .300=1.7$

\section{Aspek Sosial}

Pada gambar 5 dapat dilihat, ada nya minat masyarakat dalam memanfaatkan kascing, sebagai hasil vermicompost, untuk bercocok tanam di poly bag. Kegiatan ini merupakan inisiatif masyarakat sendiri.

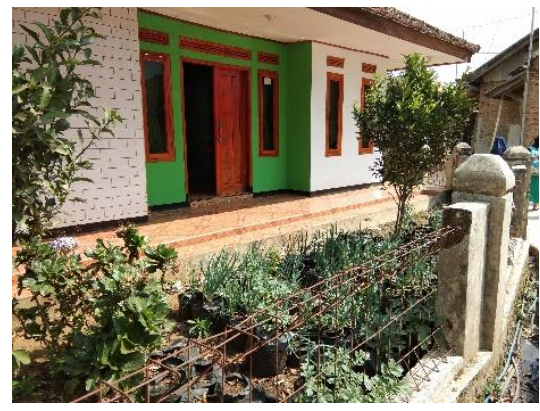

Gambar 5. Pemanfaatan Kascing pada Tanaman di Poly Bag di halaman rumah, Kampung Papak Manggu Desa Cibodas

Dari hasil observasi partisipasi dan wawancara mendalam untuk aspek sosial dapat dilihat bahwa pengelolaan kohe dengan vermicompost, dapat memberikan benefit terhadap:
- Kebersihan kandang, dan keamanan lingkungan dari pencemaran yang disebabkan oleh adanya kohe

- Memberikan penghasilan tambahan bagi petugas/pengurus ternak, atau siapapun yang memanfaatkannya

- Tersedianya pupuk organik (kascing) dengan kualitas yang baik dan harga murah Rp 250/kg, dibandingkan dengan membeli kohe ayam dari Tangerang (kebiasaan petani) dengan harga Rp 20.000/karung (50 kg)

- Tersedianya pupuk organik telah memberikan motivasi bagi ibu rumah tangga memanfaatkan pekarangan, dengan menanam sayuran sebagai dapur hidup

- Perlu dikembangkan pasar cacing kering untuk pakan ternak, hal ini dapat ditangani oleh BumDes

- Dengan ada nya kegiatan pengolahan kohe dengan vermicompost, telah mendorong terciptanya usaha pupuk organik, ternak cacing, pertanian organik dan pakan ternak.

\section{KESIMPULAN}

Dari hasil kajian sosioekonomi pemanfaatan feses sapi dengan teknologi vermicompost di Desa Cibodas, dapat ditarik kesimpulan sebagai berikut: Peternak sapi perah di desa Cibodas, 
mayoritas belum mengelola feses sapi nya secara baik dan benar. Pemanfaatan kohe sapi dengan teknologi vermicomposting sangat cocok diterapkan di Desa Cibodas, karena disamping menjadikan lingkungan kandang bersih, tenaga kerja yang dibutuhkan sedikit, juga dapat memberikan pengasilan tambahan bagi pengelola nya dengan menjual cacing dan pupuk kascing, bagi pengelolanya, dilihat dari titik pulang pokok dalam waktu 6 bulan dengan penambahan penghasilan bagi pengelola Rp 400.000 dengan waktu kerja 40 jam/bulan, dengan nilai ROI $170 \%$. Dengan menerapkan vermicompost untuk pengolahan feses sapi, maka dapat memberikan keuntungan dari sisi sosial dan ekonomi masyarakat sekitar.

\section{DAFTAR PUSTAKA}

Danilo Rogayan Jr, Vermicompost and Vermicompoting https://www.researchgate.net/ publication/316988316, May 2017.

Abdullah Hussaini, Vermiculture bio-technology: An effective tool for economic and environmental sustaina-bility, African Journal of Environmental Science and Technology Vol. 7(2), pp. 56-60, February 2013

Sri Mursiani Arifah, Analisis Komposisi pakan Cacing Lumbricus SP Terhadap Kualitas Kascing dan Aplikasinya pada tanaman Sawi , JURNAL GAMMA, ISSN 0216-8995 Volume 9 No2 versi online ejournal.umm.ac.id/index.php/ gamma/article/download/.../2709

P.K.Sarma ${ }^{1}$, P.Saikia ${ }^{2}$, T.C.Baruah ${ }^{3}$. A study on the efficiency of low cost vermicomposting structure, Proceedings of the 4th ISOFAR Scientific Conference. 'Building Organic Bridges', at the Organic World Congress 2014, 13-15 Oct., Istanbul, Turkey

Deepa Devkota1, S. C. Dhakal2, D. Dhakal3, D. D. Dhakal PhD. 4, R. B. Ojha 5. Economics of Production and Marketing of Vermicompost in Chitwan, Nepal. International Invention Journal of Agricultural and Soil Science (ISSN: 24087254) Vol. 2(7) pp. 112-117, October, 2014

Prof.Dr.Sudarwan Danim (2013) Menjadi Peneliti Kualitatif, Cetakan ke 2. Bandung : CV Pustaka Setia

Badruzzaman, D. Z. 11, W. Juanda1, Y.A. Hidayati1. Kajian Kualitas Kascing pada
Vermicomposting dari Campuran Feses Sapi Perah dan Jerami Padi. JURNAL ILMU TERNAK, DESEMBER 2016, VOL.16, NO.2 http://jurnal.unpad.ac.id/jurnalilmuternak/article/ viewFile/11575/5373 